\title{
SENI RUPA SEBAGAI STIMULASI VISUAL DALAM PEMBELAJARAN PAI UNTUK ANAK USIA SEKOLAH DASAR/MI (Tinjauan Psikologis)
}

\section{Nur Saidah}

(Dosen UIN Sunan Kalijaga Yogyakarta DPK di ISI Yogyakarta)

\begin{abstract}
According to psychological development of young child at elementary school, at least there are two main reasons of visual stimulative utilization using fine art work in teaching-learning process. The first, visual stimulation is more interesting thing to enrich child motivation in learning because the students will enjoy the process, the materials can be explained easily, teaching method will be varied and the students will involve themselves in teaching-learning process, not only listening the lesson from teacher but also observing, searching or demonstrating massage of the illustration. The second, visual stimulation is appropriate to psychological development of the children in the elementary school because this media explain the abstract concept become the concrete one and simplify the complexity of the lesson. It is very important to PAI learning process which much of it's materials consist of the abstract concept. More over using visual stimulation will give the teacher positivity to make Joyful Learning which students may learn not under pressure and the learning process of $P A I$ will be productive, full of creativities, activities, effectiveness and joyfulness.
\end{abstract}

Keywords: Visual stimulation, psikologis development.

\section{A. Pendahuluan}

Agama Islam yang diajarkan di sekolah adalah agama Islam sebagai ilmu dan sebagai agama. Sebagai agama, seorang pendidik dihadapkan pada persolan kesulitan menyusun teknologi pendidikannya karena yang akan diajarkan lebih banyak memuat konsep dan prinsip yang abstrak dan kadang sulit untuk diukur, seperti konsep iman. Di lain pihak, pendidik juga dihadapkan pada persoalan bertoleransi dengan berbagai aliran agama 
yang dianut anak didiknya. Sementara sebagai ilmu, agama Islam mengalami perkembangan yang cukup cepat karena terjadinya perkembangan kebudayaan masyarakat. ${ }^{1}$ Guru terkadang tidak mempunyai waktu luang untuk mengikuti perkembangan itu. Teori-teori baru, perkembangan pemikiran maupun metode pembelajaran agama yang menerapkan prinsip cepat dan tepat dengan memanfaatkan berbagai media yang berbasis teknologi terkadang belum diketahui guru atau terkendala penerapannya karena tidak ada fasilitas di sekolah.

Pada sisi lain,tahapan belajar pada masa kanak-kanak dan sekolah dasar yang lebih dikenal sebagai masa estetis meningkat pada masa berfikir realis konkrit adalah signifikan dan penting. Jika pada masa ini metode belajar yang dipakai tidak tepat atau salah maka kesalahan tadi akan sulit dibetulkan dan metode pada tahapan berikutnya niscaya menjadi lebih berat dijalankan. Karenanya anak sangat memerlukan stimulasi yang baik untuk mendukung perkembangannya.

Pemberian stimulasi akan lebih efektif apabila memperhatikan kebutuhan-kebutuhan anak sesuai dengan tahap-tahap perkembangannya. Stimulus yang sesuai untuk anak pada masa perkembangannya antara lain; stimulasi visual, stimulasi auditif dan stimulasi verbal berupa bahasa. Salah satu bentuk stimulasi yang bisa diberikan adalah stimulasi visual dengan memanfaatkan bidang seni rupa, misalnya menggunakan ilustrasi/gambar sebagai media pembelajaran ataupun memberikan kebebasan pada anak untuk mengekspresikan nilai-nilai Pendidikan Agama Islam melalui gambar/lukisan. ${ }^{2}$

Tulisan singkat ini berupaya mengupas upaya pemberian stimulasi belajar agama Islam bagi anak usia Sekolah Dasar/MI melalui stimulasi visual menggunakan karya seni rupa. Kajian difokuskan pada aspek psikologis anak dalam rangka membidik urgensi karya seni rupa sebagai sarana belajar anak ditinjau dari aspek kejiwaan. Diharapkan dengan tulisan ini akan berguna bagi para pendidik untuk memanfaatkan karya seni rupa sebagai alat bantu proses belajar mengajar dengan tepat sehingga proses pembelajaran menjadi lebih efektif dan menarik.

${ }^{1}$ Ahmad Tafsir, Metodologi Pengajaran Agama Islam, (Bandung: Remaja Rosda Karya, cet. 3, 1997), hlm. 21-22.

2Soetjiningsih dan IG.N. Gde Ranuh, Tumbuh Kembang Anak, (Jakarta: Penerbit Buku Kedokteran EGC, 1995), hlm. 205-114. 


\section{B. Perkembangan Pengamatan Visual dan Imajinasi Anak Usia Sekolah Dasar}

Anak usia sekolah, yang dalam psikologi perkembangan disebut dengan istilah akhir masa kanak-kanak, dimulai ketika anak usia 6 tahun sampai mereka mencapai kematangan seksual. Usia ini sering disebut sebagai masa yang menyulitkan, usia bertengkar, usia berkelompok, usia penyesuaian, atau usia kreatif ${ }^{3}$.

Dalam kajian psikologi, terdapat fungsi-fungsi kepribadian anak didik yang bersifat kejiwaan yang perlu mendapat pengembangan. Fungsifungsi tersebut adalah; fungsi perhatian, fungsi pengamatan, fantasi, tanggapan, ingatan, pikiran, perasaan dan fungsi kemauan. ${ }^{4}$ Fungsi yang dapat dikembangkan lebih lanjut dengan memanfaatkan media ilustrasi antara lain fungsi pengamatan, perhatian dan fantasi/imajinasi.

Pengamatan dan perhatian merupakan aspek tingkah laku yang mempunyai peranan penting dalam proses pembelajaran. Keefektifan suatu proses pembelajaran akan banyak dipengaruhi oleh kualitas pengamatan dan perhatian yang diberikannya. Pengamatan/perception merupakan salah satu bentuk perilaku kognitif, yaitu suatu proses mengenal lingkungan dengan menggunakan alat indera. Rangsangan itu kemudian diteruskan ke pusat kesadaran yaitu otak untuk kemudian diberikan makna/tafsiran. Dengan demikian, proses pengamatan itu berlangsung dalam 3 tahapan; pertama, penerimaan rangsangan oleh alat indera, kedua, pengiriman informasi ke pusat kesadaran/otak, ketiga, pemberian tafsiran terhadap rangsangan yang diterima. Ada 5 alat indera dalam diri manusia yang dapat digunakan untuk mengamati, yaitu mata yang menerima rangsangan cahaya, telinga yang menerima rangsangan suara, lidah penerima rangsangan rasa, hidung penerima rangsangan bebauan, dan kulit yang menerima rangasangan rabaan. Dengan demikian ada 5 macam cara individu melakukan pengamatan dengan kesemua alat indera. $^{5}$

${ }^{3}$ Khoiruddin Bashori, Problem Psikologis Kaum Santri, Risiko Insekuritas Kelekatan, (Yogyakarta: FkBA, cet. 1, 2003), hlm. 12.

4Sama'un Bakry, Menggagas Konsep Ilmu Pendidikan Islam, (Bandung: Pustaka Bani Quraiy, 2005), hlm.71-72.

${ }^{5}$ Mohamad Surya, Psikologi Pembelajaran dan Pengajaran, (Bandung: Pustaka Bani Quraisy, 2004), hlm. 70. 
Dilihat dari proporsi penggunaan alat indera, ada beberapa gaya pengamatan individu. Yaitu gaya pengamatan visual, bagi orang yang akan lebih banyak memperoleh kesan dari pengamatnnya dengan lebih banyak menggunakan mata. Gaya auditif bagi orang yang dominan penggunaan indera telinganya. Gaya taktil yang mengedepankan penggunaan perabaan/penciuman. Dan gaya kinestetik yaitu pengamatan melalui gerakan. Keefektifan pengamatan tergantung beberapa faktor, yaitu faktor rangsangan, faktor individu dan lingkungan. ${ }^{6}$ Semakin kuat rangsangan belajar yang diberikan akan memberikan pengaruh pada keefektifan pengamatan seseorang. Semakin bagus kualitas indera seseorang juga mendukung keberhasilan pengamatannya, demikian juga semakin kondusif lingkungan belajar yang diciptakan akan sangat berpengaruh pada efektifitas pengamatan seseorang.

Sementara pengamatan anak yang memasuki usia 6 tahun, di saat pada umumnya anak mulai memasuki bangku Sekolah Dasar, bentuk gambar manusia mendapat perhatian mereka, walaupun masih sangat sederhana. Warna pada tahap ini belum mendapat perhatian yang kuat, sedangkan konsep ruang hanya terbatas pada sekitar dirinya. Perkembangan persepsi visual dan pendengarannya pada stadium ini meningkat cepat meski masih terbatas pada pemahaman konkrit. Perkembangan atensinya lebih mengena pada ha-hal yang terlihat mencolok berbeda dari pada hal-hal yang relevan. Anak-anak melihat badut yang lucu lebih menarik dari pada orang-orang normal di sekitarnya. Bagi anak-anak, gambar kartun yang lucu lebih menarik dari pada foto yang realis. ${ }^{7}$ Penyajian materi ajar yang disertai gambar animasi ataupun komik menjadi sangat menarik perhatian mereka.

Pada saat memasuki usia 7-9 tahun, anak memasuki periode bagan (schematic period). Anak mulai menggambar obyek dalam suatu hubungan dengan obyek lain. Konsep ruang mulai nampak dengan pengaturan hubungan antar obyek dan ruang. Ciri-ciri khusus karyanya antara lain: 1) anak pada umumnya selalu menggunakan garis dasar tempat berpijak obyek. Muncul gejala yang disebut "folding over" yaitu cara menggambar obyek tegak lurus pada garis datar, walupun obyek akan tampak terbalik. 2) pada masa ini mucul gejala lain yang disebut gambar sinar $\mathrm{x}(x$ ray) yaitu ruangan yang sebenarnya tidak tampak. Pada tahap ini anak sudah mulai

\footnotetext{
${ }^{6}$ Ibid, hlm. 71.

${ }^{7}$ Desmita, Psikologi Perkembangan, (Bandung: Rosda Karya, 2005), hlm. 137.
} 
menyadari warna secara obyektif, adanya hubungan antara warna dan obyek, obyek tertentu tidak memiliki warna tertentu.

Pada periode awal relisme (early realism) yaitu sekitar usia 9-12 tahun, pengamatan visual anak mulai berkembang, ia mulai memperhatikan detail. Spontanitas mulai hilang, kesan gambar kaku. Karakterisasi warna mulai mendapat perhatian, namun mereka belum dapat menampilkan perubahan efek warna dalam terang dan bayang-bayang. Pada tahap ini gejala garis dasar berubah menjadi bidang dasar sebagai tempat berpijak obyek. Mulai tampak adanya kesadaran mendekorasi/menghias obyek. Anak mulai menemukan keindahan alamiah dari benda-benda di sekelilingnya. ${ }^{8}$

Di sisi lain, imajinasi sangat penting bagi anak-anak, mengingat di antara kerakteristik anak-anak adalah berkhayal dan berimajinasi yang sembarangan (tidak beraturan). Sehingga mendidik imajinasi anak memiliki urgensi edukatif melalui penyajian cerita mitos mengandung etika moral dan syarat makna yang terangkum dan dapat dicerna anak dengan mudah dan dapat mempengaruhi perhatian anak, serta menggerakkan kepekaan perasaannya. Pengembangan kecerdasan anak dapat dilakukan melalui pemaparan berbagai cerita ilmiah dan fatastis tentang penemuanpenemuan di masa depan yang dikemas dengan ilustrasi menarik. Sarana seperti ini dianggap benih mempersiapkan akal dan kecerdasan anak untuk berinovasi dan berkreativitas. ${ }^{9}$

Stimulasi visual melalui karya seni rupa baik dua dimensi seperti gambar dan lukisan maupun tiga dimensi seperti maket, patung dan bendabenda lainnya yang penuh imajinatif pada sumber-sumber belajar anak, selain sesuai dengan tahap perkembangan perhatian dan pengamatan visual serta imajinasinya, juga mampu digunakan sebagai sarana pengembangan ke arah pemikiran ilmiah pada diri anak. ${ }^{10}$ Stimulasi visual tidak hanya menarik perhatian dan minat anak, tetapi sekaligus dapat mengembangkan daya ingat anak. ${ }^{11} \mathrm{Hal}$ ini apabila diaplikasikan dalam menginternalisasikan nilai-nilai ajaran Islam akan menghasilkan pembinaan agama yang mengakar kuat di benak anak. Pembinaan tersebut penting artinya sebagai panduan pengamalan ajaran agama Islam yang benar.

${ }^{8}$ Victor Lowenfeld, Creative and Mental Growth, (The United States of America: The Macmillan Company, 1970), hlm. 89-255.

${ }^{9}$ Amal Abdussalam Al-Khalili, Mengembangkean Kreativitas Anak, (Jakarta: Pustaka alKautsar, ct. 1, 2005), hlm. 375.

${ }^{10} \mathrm{Ibid}, \mathrm{hlm} .374$.

${ }^{11}$ Amal Abdussalam Al-Khalili, Mengembangkan. 


\section{Perkembangan Kesadaran Beragama Anak Usia Sekolah Dasar.}

Perkembangan agama pada anak sangat ditentukan oleh pendidikan dan pengalaman yang dilaluinya, terutama pada masa-masa pertumbuhan pertama (masa anak) usia 0-12 tahun. Seorang anak yang pada masa itu tidak mendapat didikan agama dan tidak pernah mempunyai pengalaman keagamaan, maka ia nanti setelah dewasa akan cenderung kepada sikap negatif terhadap agama. ${ }^{12}$

Menurut Ernest Harm sebagaimana dikutip Jalaluddin, perkembangan agama anak-anak itu melalui beberapa fase (tingkatan). Dalam bukunya The Development of Religion on Children, ia mengatakan bahwa perkembangan agama pada anak-anak itu melalui tiga tingkatan, yaitu: ${ }^{13}$

a. The Fairy Tale Stage (Tingkat Dongeng). Tingkat ini dimulai pada anak yang berusia 3-6 tahun. Pada tingkatan ini konsep mengenai Tuhan lebih banyak dipengaruhi oleh fantasi dan emosi. Pada tingkat perkembangan ini anak menghayati konsep ketuhannan sesuai dengan tingkat perkembangan intelektualnya. Kehidupan masa ini masih banyak dipengaruhi kehidupan fantasi, hingga dalam menanggapi agama pun anak masih menggunakan konsep fantastis yang diliputi oleh dongeng-dongeng yang kurang masuk akal.

b. The Realistic Stage (Tingkat Kenyataan). Tingkat ini dimulai sejak anak masuk sekolah dasar hingga ke (masa usia) adolesense. Pada masa ini, ide ketuhanan anak sudah mencerminkan konsep-konsep yang berdasarkan kepada kenyataan (realitas). Konsep ini timbul melalui lembaga-lembaga keagamaan dan pengajaran agama dari orang dewasa lainnya. Pada masa ini ide keagamaan anak didasarkan atas dorongan emosional, hingga mereka dapat melahirkan konsep Tuhan yang formalis. Berdasarkan hal itu, maka pada masa ini anakanak tertarik dan senang pada lembaga keagamaan yang mereka lihat dikelola oleh orang dewasa dalam lingkungan mereka. Segala bentuk tindak (amal) keagamaan mereka ikuti dan pelajari dengan penuh minat.

c. The Individual Stage (Tingkat Individu). Pada tingkat ini anak telah memiliki kepekaan emosi yang paling tinggi sejalan dengan

${ }^{12}$ Darajat, Zakiah, Ilmu Jiwa Agama, (Jakarta: Bulan Bintang, cet. 16, 2003), hlm. 69. 13Jalaluddin, Psikologi Agama, (Jakarta: Raja Grafindo Persada, 1996), hlm. 66-67. 
perkembangan usia mereka. Konsep keagamaan yang individualistis ini terbagi menjadi tiga golongan, yaitu; (1). Konsep ketuhanan yang konvensional dan konservatif dengan dipengaruhi sebagian kecil fantasi. Hal tersebut disebabkan oleh pengaruh luar, (2). Konsep ketuhanan yang lebih murni yang dinyatakan dalam pandangan yang bersifat personal (perorangan), dan (3) konsep ketuhanan yang bersifat humanistik, artinya agama telah menjadi etos humanis pada diri mereka dalam menghayati ajaran agama. Perubahan ini setiap tingkatan dipengaruhi oleh faktor internal (perkembangan usia) dan faktor eksternal (pengaruh luar) yang dialaminya.

Sesuai dengan ciri- ciri yang mereka miliki, maka sifat agama pada anak tumbuh mengikuti pola ideas concept outhority. Ide keagamaan pada anak hampir sepenuhnya autoritarius, maksudnya konsep keagamaan pada diri mereka dipengaruhi oleh faktor dari luar diri mereka. Hal tersebut dapat dimengerti karena anak sejak usia muda telah melihat dan memperlajari hal-hal yang berada di luar diri mereka. Mereka telah melihat dan mengikuti apa yang dikerjakan dan diajarkan orang dewasa dan orang tua mereka tentang sesuatu yang berhubungan dengan kemaslahatan agama.

Adapun sifat-sifat keagamaan anak adalah: ${ }^{14}$

a. Unreflective (tidak mendalam), artinya kebenaran yang diterima anak tidak begitu mendalam, sehingga sekadarnya saja dan mereka sudah merasa puas dengan keterangan yang kadang-kadang kurang masuk akal.

b. Egosentris, artinya; dalam masalah keagamaan anak telah menonjolkan kepentingan dirinya dan telah menuntut konsep keagamaan yang mereka pandang dari kesenangan pribadinya.

c. Antromorphis, konsep mengenai ketuhanan pada anak berasal dari hasil pengamatannya di kala ia berhubungan dengan orang lain.

d. Verbalis dan Ritualis, maksudnya kehidupan agama pada anak-anak sebagian besar tumbuh mula-mula secara verbal (ucapan) dan pengalaman-pengalaman yang bersifat ritual yang pernah diajarkan.

e. Imitatif, artinya; tindak keagamaan yang dilakukan anak pada dasarnya diperoleh dari meniru. Berdo'a dan shalat misalnya

${ }^{14}$ Ibid, hlm. 70. 
mereka laksanakan karena hasil melihat perbuatan di lingukungan, baik berupa pembiasaan ataupun pengajaran intensif.

f. Rasa Heran, maksudnya adalah rasa kagum dan heran adalah sifat keagamaan yang terakhir pada anak. Berbeda dengan rasa kagum anak dengan orang dewasa, pada anak rasa kagum belum kritis dan kreatif, mereka hanya kagum terhadap luarannya saja dan karena adanya dorongan atas pengalaman yang baru.

Sementara dalam hal kesadaran beragama anak, khususnya anak usia sekolah dasar (6-12 tahun) ditandai dengan ciri-ciri: 1) sikap keagamaan yang masih bersifat reseptif namun sudah disertai dengan pengertian. 2) pandangan dan paham ketuhanan diperolehnya secara rasional berdasar kaidah-kaidah logika yang berpedoman kepada indikatorindikator alam semesta sebagai manifestasi dari keagungan-Nya. Misalnya kesadaran tentang Allah diperoleh dari penghayatan terhadap benda-benda alam yang dilihatnya dan menerima secara logis bahwa semua benda tersebut hanya diatur satu Tuhan saja yaitu Allah. Dualisme pengaturan alam tidak dapat diterima karena akan menimbulkan perebutan dan percekcokan menurut pandangan anak-anak. 3) penghayatan secara rohaniah semakin mendalam dan pelaksanaan kegiatan ritual diterimanya sebagai keharusan moral. ${ }^{15}$

Di antara hal yang perlu diingat dan selalu disadari oleh guru agama adalah anak-anak pada usia sekolah dasar sedang dalam pertumbuhan kecerdasan cepat. Khayal dan fantasinya sedang subur dan kemampuan untuk berpikir logis sedang dalam pertumbuhan. Karenanya pemberian stimulus yang dapat membangkitkan khayal dan fantasinya seperti penggunaan ilustrasi/gambar dan karya seni rupa lainnya akan sangat membantu pemahamannya. Namun perlu disadari pula bahwa anak-anak sampai usia 12 tahun belum mampu berpikir abstrak (maknawi). Oleh karena itu agama harus diberikan dalam jangkauannya yaitu dalam kehidupan nyata. Disinilah letak pentingnya pembiasaan dalam pendidikan agama. $^{16}$

${ }^{15}$ Yusuf, Syamsu, Psikologi Belajar Agama (Perspektif Agama Islam), (Bandung: Pustaka Bani Quraisy, 2005), hlm. 51 - 52.

${ }^{16}$ Zakiah Darajat, Ilmu Jiwa Agama.............hlm. 72. 


\section{Urgensi Stimulasi Visual Melalui Karya Seni Rupa Dalam Pembelajaran PAI bagi Anak MI/SD.}

Media pembelajaran harus meningkatkan motivasi belajar. Penggunaan media mempunyai tujuan memberikan motivasi kepada pembelajar. Selain itu media belajar juga harus merangsang pembelajar mengingat apa yang sudah dipelajari selain memberikan rangsangan belajar yang baru. Media belajar yang baik juga akan mengaktifkan pembelajar dalam memberikan tanggapan, umpan balik dan juga mendorong keinginan untuk melakukan praktek-praktek yang benar. ${ }^{17}$

Sebagai media pembelajaran. ilustrasi/gambar dan seni rupa pada umumnya adalah bahasa pertama yang dikenal manusia. Gambar yang masih berbentuk kode-kode ditemukan pada masa Raja Hamurabi (2067225 SM), yang dikenal dengan Hamurabi's Code. Salah satu fungsi lustrasi/gambar seperti diuraikan oleh Watson Dunn dan M. Arnold Barban adalah sebagai penyampaian suatu gagasan yang relevan secara cepat dan efektif, seringkali digunakan pada suatu yang sulit untuk dijelaskan dengan kata-kata. ${ }^{18}$

Lembaga riset dan penerbitan computer yaitu computer technology reseach (CTR) menyatakan bahwa orang hanya mampu mengingat $20 \%$ dari yang dilihat dan $30 \%$ dari yang didengar. Tetapi orang dapat mengingat $50 \%$ dari yang dilihat dan didengar, dan $80 \%$ dari yang dilihat, didengar dan dilakukan sekaligus. ${ }^{19}$ Dari penelitian tersebut, nampak jelas bahwa media visual memiliki peran yang signifikan untuk membentuk Long term memory anak, terlebih secara psikologis anak memiliki gaya pengamatan visual dan imajinasi yang lebih dominan. Media Visual yang sering ditampilkan dalam proses pembelajaran adalah dalam bentuk ilustrasi/gambar baik yang berbentuk poster maupun komik. Namun lebih jauh lagi, guru dapat mengembangkan berbagai media pembelajaran yang berbasis pada pengembangan karya seni rupa. Meskipun sederhana dan bisa menggunakan bahan-bahan dari sampah, namun penggunaan media

\footnotetext{
${ }^{17}$ Ouda Teda Ena, Membuat Media Pembelajaran Interaktif dengan Piranti Lunak Presentasi, wmw. Aitech.ac.jp, tanggal akses 10 Februari 2008.

${ }^{18}$ Watson Dunn dan Arnold M. Barban ,"Advertising It's Role and Modern Marketing”, Newyork: NY the Dryden Pres, ct. 5, 1982, hlm. 7.

${ }^{19}$ M., Suyanto, Multimedia Alat untuk. Meningkatkan Keunggulan Bersaing, Yogyakarta Penerbit Andi, 2003., hlm.23.
} 
berbasis seni rupa akan lebih menarik dan mengena di hati anak, terlebih apabila anak dilibatkan untuk membuat sendiri media tersebut.

Dalam pandangan psikologi kognitif, seperti yang dikuti Fleming (1993), ilustrasi/gambar merupakan salah satu alat penyampai pesan yang dihasilkan dengan tujuan dapat mengubah psikomotor, kesadaran atau tingkah laku efektif dari seseorang atau lebih. Pesan yang ditampilkan melalui ilustrasi/gambar dapat mendorong aktivitas belajar siswa. Hal ini terlihat dalam desain pembelajaran melalui TV/Video yang menonjolkan gambar sebagai alat yang dimuati pesan pendidikan. Berbagai riset dilakukan seperti (Knolton, 1966; :Levied dan Dickie, 1973; Peiber; 1994; dan Winn, 1987) telah membuktikan bahwa paling sedikit ada 4 riset mengenai ilustrasi/gambar. Yaitu tentang persepsi gambar, memori/gambar, pembelajaran dan kognisi serta respons yang efektif terhadap gambar. ${ }^{20}$

Teori persepsi gambar misalnya, memperkenalkan dua teori sekitar tahun 70-an berkaitan dengan persepsi gambar. James J dan Gibson yang mendasari teori mereka terhadap arti suatu pesan dilihat dari kemiripan gambar dengan lingkungan memandang arti suatu pesan berdasarkan ketentuan gambar. Kemudian teori pespektif Renaisance yang dipelopori oleh Brunelleschi yang mendasarkan teori gambar melalui layar 3 dimensi. Dalam teorinya dikemukakan bahwa pemahaman pesan didisarkan pada kemampuan pandangan menangkap kesamaan gambar dengan dunia nyata. Gambar merupakan penggati obyek, itu sebabnya gambar menjadi penting dan otomatis. Dengan demikian kekeliruan dalam menampilkan gambar akan menimbulkan persepsi pesan yang berbeda dengan obyek yang sebenarnya. ${ }^{21}$

Teori lain yang membicarakan penangkapan pesan melalui gambar seperti teori Kemiripan oleh Gipson, Consructivisme oleh Gombrich, teori Generatif oleh Hagen, teori pendekatan Gestalt oleh Arnhein, serta teori Persepsi Gambar yang dikaitkan dengan tingkah laku oleh Hochberg, yang pada intinya semua teori tersebut memandang bahwa pesan pengajaran yang dimuat melalui gambar dapat membantu pemahaman siswa.

Meskipun demikian, ada temuan menarik dari penelitian Cannon yang menyimpulkan bahwa anak membaca dengan gambar tidak

${ }^{20}$ Hamzah B. Uno, Orientasi Baru Dalam Psikologi Pembeljaran, (Jakarta: Bumi Aksara, 2006), hlm. 152-155.

${ }^{21}$ Ibid, hlm. 156. 
mendukung pengembangan imajinasinya. ${ }^{22}$ Oleh karena itu, Levin dan Lesgold menyarankan belajar dengan gambar harus disertai 5 hal; yaitu pertama dalam proses mengajar, penjelasan harus disertai dengan gambar, kedua, materi ajar harus sesuai dengan perkembangan berpikir siswa, ketiga, merupakan cerita fiktif yang bersifat naratif, keempat, gambar yang ditampilkan sesuai dengan isi cerita dan kelima, merupakan pembelajaran yang bersifat demonstratif. ${ }^{23}$

Terlepas dari beberapa kajian di atas, bukti-bukti memperlihatkan bahwa pada umumnya memori gambar lebih baik daripada memori kata. Hal ini sesuai dengan efek superioritas gambar (picture superiority effect). Paling tidak ada 3 teori yang dapat menggambarkan picture superiority effect, yaitu: teori model kode ganda, teori model kode tunggal dan teori semantik sensori. ${ }^{24}$

Dalam teori memori ganda dikatakan bahwa terdapat dua tipe memori yang saling ketergantungan yaitu verbal dan non verbal guna memproses dan menyimpan informasi. Memori verbal berfungsi memproses dan menyimpan informasi dalam bentuk kata dan kalimat, sedangkan non verbal berfungsi utuk menyimpan dan memproses informasi pada semua fenomena non verbal seperti reaksi emosional. Untuk memori tunggal, informasi visual ditransformasikan ke dalam proposisi abstrak yang tersimpan dalam memori semantik. Menurut pandangan memori tunggal, gambar mengaktifkan system memori semantik tunggal yang berbeda dengan kata-kata. Atau dengan kata lain, pada memori tunggal, sistem memori semantik dapat dimunculkan melalui gambar dan kata-kata tetapi dengan cara yang berbeda. Sementara dalam model semantik sensori, gambar-gambar kemungkinan diproses lebih baik dari pada kata. Akan tetapi dalam beberapa kasus para peneliti teknologi pendidikan menolak model-model memori ini. ${ }^{25}$

Sebagai sarana pemerolehan pengetahuan, gambar dapat dibedakan menjadi dua, yaitu gambar statis dan gambar dinamis. Ilustrasi gambar statis dapat bertindak sebagai fasilitas pemerolehan pengetahuan apabila disajikan bersamaan dengan teks materi. Akan tetapi, gambar tadi tidak bisa menjawab semua situasi belajar. Anglin dkk. menyimpulkan bahwa

${ }^{22}$ Anglin Towers \& Howard Levle, Visual Message Desigan and Learniang: The Role of Static and Dynamic Illustrations, (NewYork; Indiana University, 1993), hlm. 763.

${ }^{23} \mathrm{Hamzah}$ B. Uno. Orientasi...........................

${ }^{24}$ Uno, Ibid, hlm. 156.

${ }^{25} \mathrm{Ibid}$. 
efek-efek tampilan gambar berkenaan dengan belajar: 1) tampilan gambar yang digunakan dalam teks-teks tidak sangat membantu, 2) tampilan gambar yang berisikan informasi teks yang berulang dapat berfungsi sebagai fasilitas belajar, 3) tampilan gambar yang tidak berulang dalam teks membantu dan tidak menghalangi belajar. 4) variabel-variabel tampilan seperti ukuran, posisi halaman, gaya, warna dan derajat kenyataannya bisa berfungsi sebagai pengarah perhatian tetapi tidak secara signifikan membantu dalam belajar, dan 5) ada hubungan linier antara derajat kenyataan dalam gambar dan belajar selanjutnya. ${ }^{26}$

Sementara untuk gambar dinamis, sedikit sekali ditemukan penelitian yang berkenaan dengannya dalam kaitan efektifitasnya di bidang perolehan pengetahuan. Hanya beberapa penelitian yang dibuat oleh Rieber (1990), Park dan Hopkins (1993) yang menyatakan bahwa gambar animasi paling efektif dalam pembelajaran melalui Computer Based Instruction apabila menggunakan aplikasi grafik interaktif. ${ }^{27}$

Secara umum, gambar/ilustrasi, lukisan atau biasa disebut media visual sebagai media pembelajaran memiliki 4 fungsi: 1) fungsi atensi, yaitu menarik dan mengarahkan perhatian siswa untuk berkonsentrasi pada isi pembelajaran yang berkaitan dengan makna visual yang ditampilakan atau menyertai teks materi pelajaran. 2). Fungsi afektif, yaitu media visual dapat menimbulkan kenikmatan bagi siswa ketika belajar teks yang bergambar.3). fungsi kognitif, yaitu memperlancar pencapaian tunjuan untuk memahami dan mengingat informasi/pesan yang terkandung dalam gambar. 4). Fungsi kompensatoris yaitu mengakomodasi siswa yang lemah dan lambat menerima dan memahami isi pelajaran yang disajikan teks/verbal. ${ }^{28}$

Diantara alasan penggunaan gambar/ilustrasi dan karya seni rupa lainnya sebagai media pembelajaran adalah karena media visual dapat mempertinggi proses belajar siswa. Hal ini paling tidak karena dua hal, yaitu, pertama, media visual lebih menarik sehingga tumbuh motivasi yang tinggi dalam diri siswa, pelajaran menjadi lebih jelas maknanya, metode mengajar guru akan lebih bervariasi, siswa lebih banyak melakukan kegiatan belajar, mereka tidak hanya mendengar tetapi juga mengamati, melakukan, mendemontrasikan bahkan memainkan peran yang ada dalam

${ }^{26} \mathrm{Ibid}, 157$.

${ }^{27} \mathrm{Ibid}$.

${ }^{28}$ Azhard Arsyad, Media Pembelajaran, (Jakarta: Raja Grafindo Persada, 1997), hlm. $16-17$. 
gambar. Kedua, taraf berfikir anak mengikuti tahap perkembangannya. Penggunaan media visual erat kaitannya dengan tahapan berfikir anak usia sekolah dasar, sebab dengan media tersebut hal-hal yang abstrak dapat dikongkritkan dan hal-hal yang kompleks dapat disederhanakan. ${ }^{29}$ Apabila dikaitkan dengan prinsip pembelajaran menurut Islam, maka penggunaan media visual adalah sesuai dengan petunjuk Rosulullah SAW untuk menyesuaikan pembelajaran dengan tingkat berfikir pembelajar, memberi pembelajaran yang mudah dicerna dan menyenangkan sebagaimana sabda beliau:

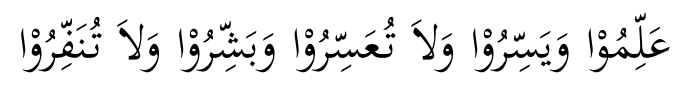

(Ajarilah dan mudahkanlah jangan mempersulit, berilah kabar gembira jangan menakuti). ${ }^{30}$

Berdasarkan uraian di atas, jelaslah bahwa kelebihan penggunaan karya seni rupa sebagai media pembelajaran terutama dapat mendekatkan pemahaman anak pada konsep yang diajarkan. Hal ini sangat sesuai apabila digunakan sebagai media pembelajaran PAI. Bahkan dewasa ini hampir semua buku ajar PAI untuk MI/SD sudah dilengkapi dengan gambar/ilustrasi, baik yang berbentuk komik maupun poster. Tentu saja sarana yang ada akan sangat memudahkan guru untuk menyampaikan materi ajar. Hanya saja guru musti mampu mengelaborasi gambar/ilustrasi tersebut sedemikian rupa sehingga anak menjadi faham dan terbangkitkan motivasi belajarnya. Guru dapat menjadikan sarana gambar yang berbentuk komik sebagai alternatif metode belajar, misalnya dengan meminta anak belajar bermain peran (role play) seperti yang ada dalam cerita komik. Atau kalau waktunya cukup terbatas, guru dapat melakukan monolog dari cerita komik, sehingga ilustrasi/gambar yang telah tersedia dalam buku ajar tidak menjadi sia-sia. Bahkan anak didik dapat diperdalam pemahamannya terhadap tema tertentu dan dapat dikembangkan kreativitasnya untuk membuat gambar, lukisan, kolase, maket, patung, dan sebagainya sesuai nilai-nilai yang diajarkan guru.

29 Nana Sudjana dan Ahmad Rivai, Media Pengajaran, (Bandung: Sinar Baru Algensindo, 2002), hlm. 2-3.

30 Jalaluddin bin Abd Rahman bin Abi Bakr as-Suyuthy, al-Jami' ash-shaghir fi Ahadits al-Basyir wan Nadžir, juz. 2, (Beirut: Dar al-Kutub al-'Arabiyah, 911 H), hlm.62. 


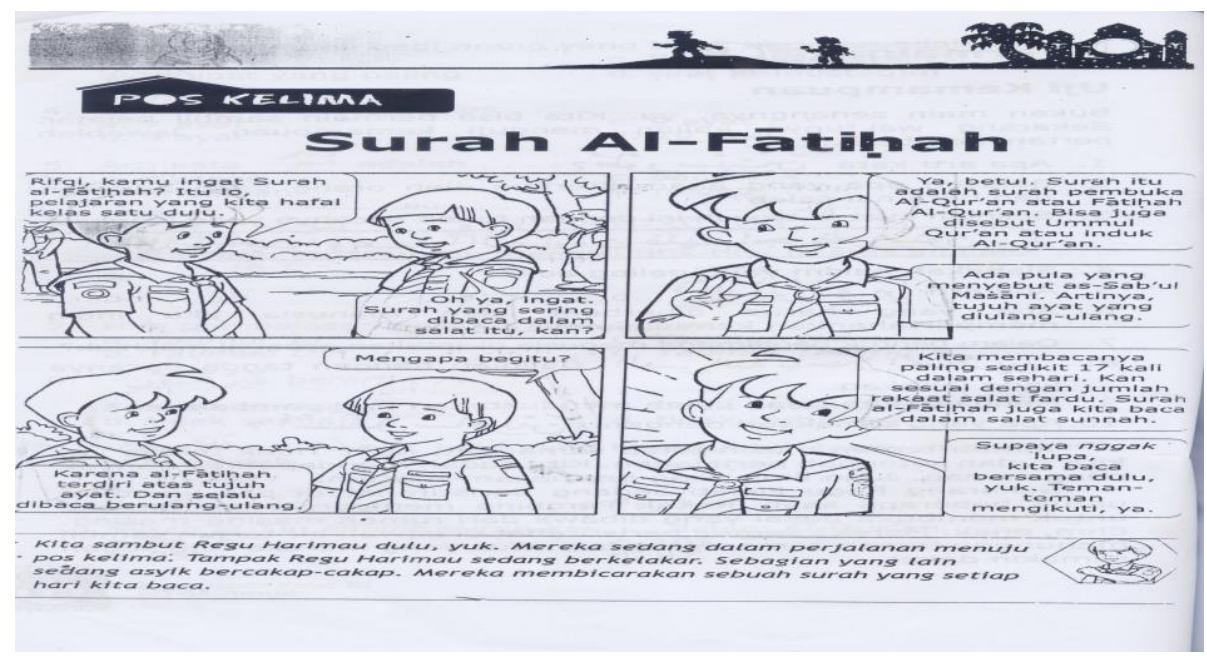

Contoh stimulasi visual dalam bentuk komik.

(Sumber: Arina Manasikana, Qur an Hadis untuk. MI Kelas III, Menjelajah Ke Gua Mabira, (Jakarta: Pustaka Insan Madani, 2006), hlm. 54.).

Memaksimalkan stimulasi visual melalui seni rupa sangat bermakna pada pengembangan pola pikir anak didik. Karena seni yang ditangkap mata akan merangsang pertumbuhan syaraf otak yang baik untuk kecerdasan pikir. Tujuan keterampilan berseni rupa diberikan kepada anak berfungsi agar anak dapat mengungkapkan perasaan dan pikiran serta angan-angan tentang diri dan lingkungannya. Dalam pembelajaran PAI, berkarya seni rupa dengan tema yang ditentukan guru sesuai materi yang dipelajari akan memperlihatkan bagaimana persepsi dan pemahaman anak terhadap pelajaran agama yang diterimanya, sehingga memudahkan guru untuk memberikan umpan balik ataupun memperdalam lagi pemahamannya. 


\section{E. Urgensi Stimulasi Visual Dalam Pembelajaran PAI bagi Guru}

Menurut Prof. Dr. Abdurrahman Mas'ud materi Pendidikan Agama Islam dewasa ini memiliki beberapa persoalan diantaranya: 1) Pengajaran materi PAI belum mampu melahirkan creativity, 2) morality/akhlak di sekolah masih menjadi masalah utama, 3). Punishment/azab masih lebih dominan dari pada reward/ajr. Menurut beliau, akar persoalan pertama, yaitu persoalan pengajaran PAI belum mampu melahirkan kreativitas adalah karena beban pengajaran di kurikulum sekolah-sekolah di Indonesia cenderung overload. Terbukti libur hanya 1 hari dalam 1 minggu, lebih berat dibandingkan dengan beban kerja orang dewasa yang mendapat libur di hari sabtu dan minggu. Jika beban anak lebih berat, tentu sulit diharapkan anak akan belajar di waktu-waktu ekstranya di rumah. Anak dituntut dengan pekerjaan rumah (PR), les privat, bahkan PR dikerjakan di hari libur. Kurikulum yang terlalu padat hanya akan membuat exhausted/kelelahan yang berlebihan sehingga akibatnya anak akan kekeringan creativity. Pola pendidikan seperti ini, lagi-lagi merupakan pola What-Oriented Education, lebih menekankan pada materi pengajaran tanpa memperhatikan kemampuan siswa. ${ }^{31}$

Sementara metode penyampaian PAI yang lebih menekankan punishment daripada reward akan terefleksi dalam pola pemahaman dasar keberagamaan muslim Indonesia secara umum, bahwa kata takwa diartikan dan diimplementasikan sebagai "takut kepada Tuhan" bukan cinta Tuhan/conscious, sadar akan keberadaan Tuhan, di mana saja kapan saja. Pola ketuhanan pasif bukan aktif, disadari atau tidak hal ini telah berkembang ke dunia pendidikan Islam kita yang lebih mengkondisikan anak didik dalam "suasana takut" atau bahkan tertindas baik oleh guru maupun materi yang harus dihafalkan terus menerus. ${ }^{32}$

Di sinilah pentingnya memperhatikan segi-segi psikologis dalam menyampaikan materi kepada anak-anak agar terhindar dari kebosanan bahkan dapat meningkatkan daya imajinasi dan kreativitasnya, yaitu dengan memanfaatkan karya seni rupa misalnya media gambar/ilustrasi sebagai alat belajar. Tentu saja untuk efektivitas penyajian gambar harus disertai teks tertulis yang berkaitan dengan materi.

${ }^{31}$ Abdurrahman Mas'ud, Menggagas Format Pendiikan Non Dikotomike (Humanisme Religius Sebagai Paradigma Pendidikan Islam), (Yogyakarta: Gama Media, 2002),hlm. 206.

${ }^{32} \mathrm{Ibid}, \mathrm{hlm} .207$. 
Seorang guru yang profesional melihat hasil belajar siswanya dari berbagai sudut kinerja psikologis yang utuh dan menyeluruh yang ditandai dengan munculnya pengalaman psikologis yang baru dan positif, sehingga diharapkan dengan pengalaman tersebut seorang siswa dapat mengembangkan aneka ragam sifat, sikap dan kecakapan konstruktif dan bukan yang destruktif. Hal ini menuntut peran seorang guru untuk bisa memanfaatkan media visual yang secara psikologis tidak diragukan lagi efektifitasnya untuk dimafaatkan sebagai penggerak motivasi siswanya, mengembangkan perbendaharaan kata dan keterampilan membacanya sekaligus membangkitkan minat gemar membaca kepada siswa.

Selain itu, pembelajaran agama dengan menggunakan karya seni rupa sebagai media visual justru memudahkan seorang guru dalam menciptakan pembelajaran yang menyenangkan (Joyful Learning). Yaitu sebuah pembelajaran yang didalamnya terdapat kohesi yang kuat antara pengajar dan peserta didik dengan tanpa ada perasaan tertekan (not under pressure). Pembelajaran yang menyenangkan mengedepankan aktivitas dan kreativitas siswa. ${ }^{33}$ Pembelajaran yang dilakukan dengan kegembiraan akan memperlambat kelelahan, baik pada pihak guru maupun siswa. Pada segi lain pembelajaran yang diisi dengan kegembiraan dapat membantu menjaga pemusatan perhatian. ${ }^{34}$ Guru dapat memanfaatkan media visual yang tersedia dalam buku ajar PAI untuk MI sebagai media mengaktifkan siswa melalui simulasi, game, team quiz, ataupun role playing. Dengan demikian seorang guru PAI yang memanfaatkan stimulasi visual dapat menciptakan 'kegembiraan' dalam pembelajaran, dalam arti guru mampu membangkitkan minat siswa, mengajaknya terlibat penuh dalam pembelajaran, serta terciptanya makna, pemahaman (penguasaan materi), dan nilai yang membahagiakan pada diri siswa. ${ }^{35}$

Namun demikian, pengembangan karya seni rupa sebagai media belajar agama Islam perlu memperhatikan prinsip-prinsip karya seni rupa Islami. Yaitu seni Budaya Islam yang diartikan sebagai ekspresi tentang keindahan wujud dari sisi pandangan Islam tentang alam, hidup dan manusia yang mengantar menuju pertemuan sempurna antara kebenaran

${ }^{33}$ Syuaeb Kurdi, Abdul Aziz, Model Pembelajaran Efektif PAI di SD dan MI, (Bandung: Pustaka Bani Quraisy, 2006), hlm. 105.

${ }^{34}$ Ahmad Tafsir, Metodologi Pengajaran. hlm. 26.

${ }^{35}$ Hernowo, Menjadi Guru yang Mau dan Mampu Mengajar Secara Menyenangkan, (Bandung: MLC Mizan, 2007), hlm. 17. 
dan keindahan (sesuai cetusan fitrah). ${ }^{36}$ Dengan memahami prinsip tersebut, maka tidak selayaknya seorang guru PAI ketika mengembangkan media belajar berbasis seni rupa memerintahkan anak didiknya membuat gambar yang melanggar ajaran Islam. Ataupun membuat dan meminta siswa untuk melukis Nabi Muhammad SAW. Sebab menggambarkan sosok Nabi terutama Nabi Muhammad SAW secara figuratif dikhawatirkan akan mereduksi nilai keteladanan beliau atau memungkinkan orang lain melihat lukisan tersebut dengan perspektif yang negatif jauh dari yang seharusnya dalam idealitas pandangan Islam tentang Nabi Muhammad SAW. Demikian juga dengan konsep-konsep ghaib yang tidak memungkinkan untuk divisualisasikan dengan tepat selayaknya tidak divisualkan. Seperti konsep malaikat, jin, syaithan, buroq dan sebagainya. Penggambaran konsep-konsep agama yang ghaib dikhawatirkan akan memunculkan persepsi yang salah di benak anak didik. Hal ini bukan berarti justru membatasi ruang gerak guru dalam membuat media visual, namun justru memacu kreativitasnya untuk mencari alternatif lain sekaligus menjelaskan kepada anak didik mengapa hal-hal ghaib dalam agama Islam tidak dapat divisualkan tetapi cukup dipercayai dengan yakin. Konfirmasi materi yang berkaitan dengan hal-hal ghaib juga dimungkinkan terjadi setelah pemanfaatan karya seni rupa sebagai media belajar. Sebab dalam pandangan anak seringkali Allah juga digambarkan seperti manusia yang melihat dengan mata, mendengar dengan telinga, bertahta seperti raja, dan sebagainya. Ketika imajinasi anak menyentuh hal-hal ghaib yang ternyata tidak sesuai dengan pandangan Islam maka guru memiliki ruang untuk meluruskan pemahaman keagamaan anak.

\section{Penutup.}

Penggunaan stimulasi visual menggunakan karya seni rupa dalam pembelajaran PAI untuk siswa di Sekolah Dasar dan Madrasah Ibtidaiyah dapat memberikan manfaat bagi siswa maupun guru. Bagi siswa SD/MI yang notabene memiliki karakteristik pengamatan visual dan imajinasi yang lebih menonjol serta karakteristik kesadaran beragama yang masih bersifat reseptif dan autoritarius akan membangkitkan minat belajar dan mempermudah pemahaman terhadap konsep-konsep dan prinsip-prinsip

${ }^{36}$ M. Quraish Shihab, "Islam dan Kesenian”, dalam Jabrohim dan Saudi Berlian (ed.), Islam dan Kesenian, (Yogyakarta: MKM UAD Lembaga Litbang PP Muhammadiyah, 1995), hlm.7 \& 193. 
dalam materi PAI yang mayoritas bersifat abstrak. Stimulasi visual juga memungkinkan siswa belajar dengan penuh kegembiraan, kreatif dan terlibat secara penuh dalam pembelajaran. Sedangkan bagi guru PAI, stimulasi visual akan mempermudah guru menciptakan variasi pembelajaran, mempermudah penjelasan yang kongkrit dan tidak rumit serta membantunya dalam pelaksanaan konsep belajar yang PAKEM (produktif, aktif, kreatif, efektif dan menyenangkan) yang tentu saja sangat mendukung upaya meningkatkan profesionalisme guru dalam hal pengelolaan kelas maupun menyajikan materi dengan metode yang variatif. 


\section{DAFTAR PUSTAKA}

Al-Khalili, Amal Abdussalam,Mengembangkan Kreativitas Anak, Jakarta: Pustaka al-Kautsar, ct. 1, 2005.

Anglin, Towers \& Howard Levle, Visual Message Desigan and Learniang: The Role of Static and Dynamic Illustrations, NewYork; Indiana University, 1993.

Arsyad, Azhard Media Pembelajaran, Jakarta: Raja Grafindo Persada, 1997.

Bakry, Sama'un, Menggagas Konsep Ilmu Pendidikan Islam, Bandung: Pustaka Bani Quraiy, 2005.

Bashori, Khoiruddin Problem Psikologis Kaum Santri, Risiko Insekuritas Kelekatan, Yogyakarta: FkBA, cet. 1, 2003.

Crow, Alice, An Outline Of Educational Psychology, Iowa: Littlefield, Adams and Co, 1958.

Darajat, Zakiah, Ilmu Jiwa Agama, Jakarta: Bulan Bintang, cet. 16, 2003.

Desmita, Psikologi Perkembangan, Bandung: Rosda Karya, 2005.

Dunn, Watson dan Barban, Arnold, M. "Advertising It's Role and Modern Marketing”, Newyork: NY the Dryden Pres, ct. 5, 1982.

Ena, Ouda Teda, Membuat Media Pembelajaran Interaktif dengan Piranti Lunak Presentasi, wnw. Aitech.ac.jp, tanggal akses 10 Februari 2008.

Hernowo, Menjadi Guru yang Mau dan Mampu Mengajar Secara Menyenangkan, Bandung: MLC Mizan, 2007.

Jalaluddin, Psikologi Agama, Jakarta: Raja Grafindo Persada, 1996.

Kurdi, Syuaeb Abdul Aziz, Model Pembelajaran Efektif PAI di SD dan MI, Bandung: Pustaka Bani Quraisy, 2006.

Lowenfeld, Victor, Creative and Mental Growth, The Macmillan Company, The United States of America, 1970.

Manasikana, Arina, Qur an Hadis untuk. MI Kelas III, Menjelajah Ke Gua Mahira, Jakarta: Pustaka Insan Madani, 2006.

Mas'ud, Abdurrahman, Menggagas Format Pendiikan Non Dikotomik (Humanisme Religius Sebagai Paradigma Pendidikan Islam), Yogyakarta: Gama Media, 2002.

Soetjiningsih dan IG.N. Gde Ranuh, Tumbuh Kembang Anak, Jakarta: Penerbit Buku Kedokteran EGC, 1995. 
Sudjana, Nana dan Ahmad Rivai, Media Pengajaran, Bandung: Sinar Baru Algensindo, 2002.

Surya,Mohamad, Psikologi Pembelajaran dan Pengajaran, Bandung: Pustaka Bani Quraisy, 2004.

Suyanto, M., Multimedia Alat untuk Meningkatkan Keunggulan Bersaing, Yogyakarta,Penerbit Andi, 2003.

Tafsir, Ahmad, Metodologi Pengajaran Agama Islam, Bandung: Remaja Rosda Karya, cet. 3, 1997.

Uno, Hamzah, B. Orientasi Baru Dalam Psikologi Pembeljaran, Jakarta: Bumi Aksara, 2006.

Yusuf, Syamsu, Psikologi Belajar Agama (Perspektif Agama Islam), Bandung: Pustaka Bani Quraisy, 2005. 